\title{
Methionine sulphoxide as a source of sulphur-containing amino acids for the young rat
}

\author{
By ANNE U. GJØEN AND L. R. NJAA \\ Government Vitamin Institute, Directorate of Fisheries, 5000 Bergen, Norway
}

(Received I6 February I976-Accepted I7 May 1976)

\begin{abstract}
I. Young male rats were used in five experiments to study the utilization for growth of methionine sulphoxide, and the relationship between the sulphoxide content in the diet and the level of microbiologically determined methionine activity in blood or blood plasma. In one nitrogen-balance experiment methionine and methionine sulphoxide were compared as supplements to a casein diet and a fish-meal diet.

2. Methionine sulphoxide was poorly utilized for growth when tested as the sole sulphur amino acid in an amino acid diet. Substitution of one-third of the sulphoxide with cystine improved utilization so that it approached that of methionine.

3. Methionine alone and in combination with methionine sulphoxide were added to a soya-bean-meal diet. The sulphoxide showed no adverse effect on growth.

4. Fish meal in which methionine had been oxidized to methionine sulphoxide was tested alone and in combinations with unoxidized fish meal. Only when the oxidized meal was given alone was there an appreciable effect on growth. The fish meals used were low in cystine.

5. Whereas both methionine and methionine sulphoxide improved the $\mathrm{N}$ balance when a casein diet was given, there was no effect when a fish-meal diet was given.

6. There was a linear relationship between methionine sulphoxide content in the amino acid diets and the methionine activity in the blood plasma. Methionine sulphoxide added to a soya-bean-meal diet or present in oxidized fish meal gave a curvilinear relationship, and the observed activities were lower than with the amino acid diets. Methionine activity in blood could not be used as an indicator of moderate amounts of methionine sulphoxide in protein-containing diets.
\end{abstract}

The possibility that methionine may be oxidized to the sulphoxide stage during food processing has been pointed out by several authors (Lea, Parr \& Carpenter, I958; Tannenbaum, Barth \& LeRoux, I969; Miller, Tannenbaum \& Seitz, I970; Rasekh, Stillings \& Sidwell, I972; Cuq, Provansal, Guilleux \& Cheftel, 1973). However, experimental evidence seems to be lacking, probably because of difficulties involved in differential determination of methionine and methionine sulphoxide in crude proteins. Because methionine sulphoxide is partly reduced to methionine during acid hydrolysis (Njaa, 1962a; Floyd, Cammaroti \& Lavine, 1963) it cannot be determined in routine amino acid analysis. We have, however, had results (Gjøen \& $\mathrm{Njaa}$, unpublished results) indicating that up to one-third of the methionine in fish meal may be in the sulphoxide form. These results were obtained by determining methionine sulphoxide in intact proteins by the method proposed by Lunder (1972), and comparing these results with results obtained for total methionine by ion-exchange chromatography.

It is of obvious interest to know to what extent methionine sulphoxide is available as a methionine source or as a source of sulphur-containing amino acids. The availability of free and of peptide-bound methionine sulphoxide for the young rat has been studied by several authors with conflicting results. Methionine sulphoxide was found 
to be equally well utilized as methionine when it was added to diets in which the $\mathrm{S}$ amino acids were the limiting factor (Bennett, 1939; Tsuchiya, I942 $a, b$; Njaa, $1962 b$ ) whereas Miller \& Samuel $(1968,1970)$ found the sulphoxide to be less well utilized than methionine. Similarly Miller et al. (1970) found poorer utilization of methionine sulphoxide than of methionine when the sulphoxide replaced methionine in a synthetic amino acid mixture. Protein-bound methionine sulphoxide in casein was found to be less well utilized than methionine by Ellinger \& Palmer (I969) whereas Slump \& Schreuder (1973) concluded that methionine oxidized to the sulphoxide stage was completely available both in casein and in fish meal.

The experiments in which poor utilization of methionine sulphoxide was reported were all carried out with diets either devoid of cystine (Miller et al. 1970) or with casein which is low in cystine (Miller \& Samuel, 1968, 1970; Ellinger \& Palmer, 1969). We therefore investigated the effect of cystine on the utilization of methionine sulphoxide for growth.

Miller et al. (1970) also reported that the feeding of methionine sulphoxidecontaining diets resulted in a very high methionine activity in blood plasma as measured microbiologically. We also studied this aspect because we hoped that determination of the methionine activity in the blood might be an indicator of methionine sulphoxide in protein sources.

\section{EXPERIMENTAL}

\section{Animals and diets}

Five growth experiments and one nitrogen-balance experiment were performed. Young male albino rats of our own breed were used in all experiments. The rats weighed about $60 \mathrm{~g}$ initially and they were kept on the experimental diets for 10-20 d in the growth experiments and for $9 \mathrm{~d}$ in the $\mathrm{N}$-balance experiment. Litter-mate control was employed so that each treatment group contained one rat from each of four to six litters. The rats were weighed at the start and every 3 or $4 \mathrm{~d}$; in the Nbalance experiment the weighings were at the start, after the preliminary period of $4 \mathrm{~d}$, and after the $5 \mathrm{~d}$ collection period. Feeding was at the same time each day; in Expts $1-3,5$ and 6 it was necessary to mix the daily ration with water to avoid spilling, but in Expt 4 the ration was given dry. In the growth experiments the rats were fed ad lib., and the amount of food given daily was increased according to the observed appetites so that the amounts left in the feeding cups were kept at a minimum. Records of food consumption were kept for each rat. In the N-balance experiment the rats were given $8 \mathrm{~g}$ food on the first day of the preliminary period, $9 \mathrm{~g}$ on the second day and $10 \mathrm{~g}$ for the rest of the experiment. The food offered was eaten completely. The compositions of the diets used are given in Table I. The diets used in Expts $1-3$ were essentially as described by Miller $e$ t al. (1970); the amino acid mixture was, however, slightly modified so that it contained more serine and less glycine, bringing the amino acid pattern more in line with that of fish meal on this point.

The amino acid composition of the amino acid mixture used, and the protein contents as well as the amino acid contents of the protein sources used are given in 
Table I. Composition of the experimental diets* $(\mathrm{g} / \mathrm{kg})$ given to rats

\begin{tabular}{|c|c|c|c|c|c|}
\hline \multirow[b]{2}{*}{ Ingredients } & \multirow[b]{2}{*}{ Expts $I-3$} & \multirow[b]{2}{*}{ Expt 4} & \multirow[b]{2}{*}{ Expt 5} & \multicolumn{2}{|c|}{ Expt 6} \\
\hline & & & & (a) & (b) \\
\hline $\begin{array}{l}\text { Amino acid mixture (without } \\
\text { the } S \text { amino acids) }\end{array}$ & 145 & - & - & - & - \\
\hline Sodium acetate & 12 & - & - & - & - \\
\hline $\mathrm{S}$ amino acid supplement & 9 or $6 \dagger$ & 4.5 & - & 0.8 & 0.8 \\
\hline Soya-bean meal $\ddagger$ & - & 300 & - & - & - \\
\hline Fish meal no. $I$ and no. $2 f$ & - & - & $148 \mathrm{CP}$ & - & - \\
\hline Fish meal no. $3 \ddagger$ & - & - & - & $11_{3}$ & - \\
\hline Casein & - & - & - & - & 98 \\
\hline Vitamin mixture§ & $\mathrm{I} 2$ & 12 & 12 & - & - \\
\hline Mineral mixture & 40 & 40 & 40 & 40 & 40 \\
\hline Groundnut oil & 50 & 50 & 50 & 50 & 50 \\
\hline Sucrose & 200 & 200 & 200 & 200 & 200 \\
\hline $\begin{array}{l}\text { Partly dextrinized potato } \\
\text { starch }\end{array}$ & 532 & 398 & $498-484$ & 597 & 612 \\
\hline $\mathbf{C P}$ & - & 146 & 148 & 80 & 80 \\
\hline
\end{tabular}

* Details of the amino acid composition of the amino acid mixture and of the protein sources are given in Table 2, and details of the amino acid additions in Tables 3, 4 and 5 .

$\dagger$ The value 9 refers to Expts 1 and $2 a, 6$ refers to Expts $2 b$ and 3 .

I The soya-bean meal was a solvent extracted commercial meal, fish meal no. I was a commercial, white fish meal from fish fillet trimmings, fish meal no. 2 was prepared in the laboratory from fish meal no. I, fish meal no. 3 was a commercial capelin meal.

$\S$ In Expts $\mathrm{I}-5$ the following vitamin mixture was used ( $\mathrm{mg} / \mathrm{kg}$ diet): thiamin 12 , riboflavin I2, pyridoxine. $\mathrm{HCl} 12$, calcium pantothenate 36, myo-inositol 600 , nicotinic acid $60, p$-aminobenzoic acid 120 , biotin 0.24 , cyanocobalamin 0.024 , cholinehydrogentartrate 2400 , pteroylmonoglutamic acid 2.4 menaphthone 6, retinol $\mathrm{I} \cdot 8$, cholecalciferol $0.03, \alpha$-tocopherol 80 . In Expt 6 vitamins were added as described by Njaa (1959).

If The mineral mixture was modified from Greenfield, Briggs, Watson \& Yudkin (I969) (g/kg diet): $\mathrm{Ca}_{3}\left(\mathrm{PO}_{4}\right)_{2} \mathrm{I}_{4} \cdot 4, \mathrm{CaCO}_{3} 3 \cdot 8, \mathrm{KCl} 8 \cdot 2, \mathrm{NaCl}_{2} \cdot 0, \mathrm{Na}_{2} \mathrm{HPO}_{4} 7 \cdot 4, \mathrm{MgSO}_{4} \cdot \mathrm{H}_{2} \mathrm{O} 2 \cdot 8, \mathrm{MnSO}_{4} . \mathrm{H}_{2} \mathrm{O}$ o. $\mathrm{I}_{\text {, }}$ ferric-citrate pentahydrate $0.174, \mathrm{ZnCO}_{3} 0.03, \mathrm{CuSO}_{4} 0.015, \mathrm{KIO}_{3} 0.001, \mathrm{TiO}_{2} \mathrm{I} \cdot 0$.

$\mathrm{CP}$, crude protein (nitrogen $\times 6 \cdot 25$ ).

Table 2. The protein or amino acid contents of the diets were $140-150 \mathrm{~g} / \mathrm{kg}$ in the growth experiments and $80 \mathrm{~g} / \mathrm{kg}$ in the $\mathrm{N}$-balance experiment. The oxidized fish meal (no. 2) was prepared from fish meal no. I essentially by the method described by Slump \& Schreuder (1973). A barium hydroxide hydrolysate of this meal contained methionine sulphoxide but no methionine as determined chromatographically.

\section{Analytical methods}

Crude protein $(\mathrm{N} \times 6.25)$ was determined in food ingredients, diets, faeces and urine by a micro-Kjeldahl technique as previously described ( $\mathrm{Njaa}$, I963). Amino acids were determined in a Technicon Amino Acid AutoAnalyzer (Technicon Instrument Corp., Tarry Town, New York, USA) using the $130 \mathrm{~cm}$ column and Technicon resin $B$. The chromatograms were run for about $20 \mathrm{~h}$ using Autograd gradient elution. The standard Autograd was employed with the protein concentrates hydrolysed with $6 \mathrm{M}-\mathrm{HCl}$. The Autograd described by Cuq et al. (1973) was used when barium hydroxide hydrolysates and deproteinized plasma were analysed.

Samples containing about $250 \mathrm{mg}$ protein were hydrolysed with $900 \mathrm{ml} 6 \mathrm{M}-\mathrm{HCl}$ for $23 \mathrm{~h}$ under reflux in a nitrogen atmosphere. After dilution to $\mathrm{I} 1$, $100 \mathrm{ml}$ were 
Table 2. Amino acids in the amino acid mixture $(\mathrm{g} / \mathrm{kg})$ and in the protein sources $(\mathrm{g} / \mathrm{kg} \mathrm{CP})$, and protein content of the protein sources $(\mathrm{g} / \mathrm{kg})$

\begin{tabular}{|c|c|c|c|c|c|c|}
\hline & & & & ish meal & & \\
\hline & $\begin{array}{l}\text { Amino acid } \\
\text { mixture }\end{array}$ & $\begin{array}{l}\text { Soya-bean } \\
\text { meal }\end{array}$ & No. I & No. $2 f$ & No. 3 & Casein \\
\hline Total $\mathrm{S}$ amino acids $\uparrow$. & ... $60-40$ & 33 & 36 & 34 & 40 & $3 I$ \\
\hline $\begin{array}{l}\text { Methionine plus } \\
\text { methionine sulphoxide }\end{array}$ & - & 14 & 30 & 29 & $3 \mathbf{I}$ & 26 \\
\hline Cystine & - & I 5 & 5 & 4 & 7 & 4 \\
\hline Aspartic acid & 19 & 115 & I 18 & 114 & 96 & 68 \\
\hline Threonine & 44 & 43 & 43 & $3^{8}$ & 46 & 37 \\
\hline Serine & 37 & 53 & 52 & $4 I$ & 47 & 55 \\
\hline Glutamic acid & $232-252$ & 180 & 143 & 160 & 150 & 220 \\
\hline Proline & 55 & 44 & 47 & 36 & 45 & 90 \\
\hline Glycine & 57 & 43 & 87 & 62 & 64 & 17 \\
\hline Alanine & I9 & 43 & 63 & 55 & 67 & 28 \\
\hline Valine & 48 & 46 & 49 & 54 & 55 & 61 \\
\hline Isoleucine & 48 & 45 & 42 & 45 & 46 & 48 \\
\hline Leucine & 63 & 78 & 71 & $8 I$ & 83 & $9 \mathrm{I}$ \\
\hline Tyrosine & 26 & 40 & 35 & 37 & 36 & $5^{6}$ \\
\hline Phenylalanine & 63 & 50 & 38 & 44 & 40 & 49 \\
\hline Lysine & 80 & 68 & 76 & IOI & 87 & 77 \\
\hline Histidine & 22 & 29 & I9 & 20 & 23 & 29 \\
\hline Arginine & 82 & 77 & 69 & 69 & 65 & 32 \\
\hline Tryptophan & I3 & 17 & 13 & 10 & 12 & 12 \\
\hline Asparagine & 33 & $\rightarrow$ & - & - & $\cdots$ & - \\
\hline $\mathrm{CP}$ & - & 488 & 740 & 710 & 704 & $8 I 5$ \\
\hline
\end{tabular}

$\mathrm{CP}$, crude protein (nitrogen $\times 6 \cdot 25$ ).

* For composition see Table I.

$\dagger$ The $\mathrm{S}$ amino acids are given as methionine equivalents.

$\ddagger$ Fish meal no. 2 was prepared from fish meal no. I by oxidizing according to the method described by Slump \& Schreuder (1973).

taken to dryness in a rotary evaporator, the residue dissolved in $50 \mathrm{ml} 0 . \mathrm{I} \mathrm{M}-\mathrm{HCl}$ and $\mathrm{r} \mathrm{ml}$ of this solution was taken for chromatography.

Hydrolysates for tryptophan determination and for methionine sulphoxide detection were prepared as described by Slump \& Schreuder (1969). Tryptophan was determined as described by these authors. For the methionine sulphoxide detection an aliquot of the hydrolysate was treated with sulphuric acid to precipitate barium, centrifuged and adequately diluted before chromatography. Plasma for these determinations was deproteinized by treating a volume with an equal volume of dilute sulphosalicylic acid ( $100 \mathrm{~g} / \mathrm{l})$. After centrifugation $\mathrm{I} \mathrm{ml}$ was taken for chromatography.

At the end of the growth experiments the feeding cups were removed in the morning and the rats were left without food for $4 \mathrm{~h}$. They were then weighed, anaesthetized with diethyl ether and decapitated. Blood was collected in heparinized tubes separately for each rat. In Expts 2-5 the separate samples were analysed; in Expt I a pooled sample for each group was used. The blood was centrifuged for to min at $3000 \mathrm{rev} . / \mathrm{min}$, and the plasma was stored frozen. The methionine activity in deproteinized plasma was determined by a modification of the method described by McLaughlan, Noel, Morrison \& Campbell (r96r) using Pediococcus cerevisiae (ATCC 8042) as test organism. In these assays sodium tungstate was used for the deproteinization, as described by the same authors. L-methionine was used as the 
Table 3. Mean food intakes $(g / d)$, body-weight gains $(g / d)$ and methionine $(M)$ activities in blood plasma $(\mu \mathrm{g} / \mathrm{ml})$ of rats given the amino acid mixture ( $a-a$ mix) with additions of methionine, methionine sulphoxide $(S)$, cystine $(C)$ or combinations of these for 10 and $17 d$ (Expt $\mathrm{I}$ ) or for $10 d$ (Expts $2 a, 2 b$ and 3 )

(Groups of six male rats)

\begin{tabular}{|c|c|c|c|c|c|c|c|}
\hline \multirow[b]{2}{*}{ Expt I } & & & & & & \multicolumn{2}{|c|}{$\begin{array}{c}\text { Statistical significance } \\
(P)\end{array}$} \\
\hline & & & & & & & 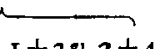 \\
\hline Group no. $\quad \ldots$ & $\cdots$ & 2 & 3 & 4 & SE & $I+2 v \cdot 3+4$ & $I+3 v .2+4$ \\
\hline $\begin{array}{l}\text { Additions to a-a } \\
\text { mix }\end{array}$ & M & $\mathrm{M}+\mathrm{C}$ & $\mathbf{S}$ & $\mathrm{S}+\mathrm{C}^{*}$ & 一 & 一 & 一 \\
\hline $\begin{array}{l}\text { Amounts added } \\
(\mathrm{g} / \mathrm{kg})\end{array}$ & 60 & $40+16$ & 66 & $44+16$ & 一 & 一 & 一 \\
\hline Food intake & & & & & & & \\
\hline$(\mathrm{g} / \mathrm{d})$ IO d & $9 \cdot 4$ & $9 \cdot 4$ & $8 \cdot 1$ & $9 \cdot 4$ & - & 一 & 一 \\
\hline $\begin{array}{r}\text { I } 7 \mathrm{~d} \\
\text { Weight gain }\end{array}$ & $12 \cdot I$ & $12 \cdot 3$ & 8.9 & I I 8 & 0.17 & $<0.001$ & $<0.001$ \\
\hline (g/d) ro d & $3.8 \mathrm{I}$ & 3.71 & $I \cdot 90$ & $3 \cdot 46$ & 0.10 & $<0.001$ & $<0.00 \mathrm{r}$ \\
\hline $\begin{array}{l}\text { M activity } \\
(\mu \mathrm{g} / \mathrm{ml}) \text { I7 } \mathrm{d}\end{array}$ & $\begin{array}{l}4 \cdot 79 \\
5\end{array}$ & $\begin{array}{l}5^{\circ} 03 \\
6\end{array}$ & $\mathrm{3}_{310}^{\mathrm{I} \cdot 83}$ & $148 \dagger^{4.59}$ & $\stackrel{0.10}{-}$ & $\begin{array}{c}<0.001 \\
-\end{array}$ & $\begin{array}{c}<0.001 \\
-\end{array}$ \\
\hline Expt $2 a$ & & & & & & & \\
\hline Group no. $\quad \ldots$ & $\cdots$ & 2 & 3 & SE & & $2 v \cdot x+3$ & I ข. 3 \\
\hline $\begin{array}{l}\text { Additions to } \mathrm{a}-\mathrm{a} \\
\mathrm{mix}\end{array}$ & $\mathrm{M}+\mathrm{C}$ & $\mathbf{S}$ & $\mathrm{S}+\mathrm{C}^{*}$ & - & & - & - \\
\hline $\begin{array}{l}\text { Amounts added } \\
(\mathrm{g} / \mathrm{kg})\end{array}$ & $40+r 6$ & 66 & $44+16$ & 一 & & $一$ & - \\
\hline Food intake $(\mathrm{g} / \mathrm{d})$ & $8 \cdot 5$ & 5.7 & $8 \cdot 3$ & 0.37 & & $<0.001$ & Ns \\
\hline Weight gain (g/d) & $5 \cdot 06$ & $x \cdot 64$ & $4 \cdot 65$ & 0.37 & & $<0.001$ & Ns \\
\hline $\mathrm{M}$ activity $(\mu \mathrm{g} / \mathrm{ml})$ & 6 & $35 \mathrm{I}$ & 246 & $23.9 \ddagger$ & & $<0.001$ & $<0.001$ \\
\hline Expt $2 b$ & & & & & & & \\
\hline Group no. $\quad \ldots$ & $\ldots$ & 2 & 3 & SE & & $2 v .1+3$ & I $v \cdot 3$ \\
\hline $\begin{array}{l}\text { Additions to a-a } \\
\text { mix }\end{array}$ & $M+C$ & $\mathrm{~S}$ & $\mathrm{~S}+\mathrm{C} *$ & - & & - & - \\
\hline $\begin{array}{l}\text { Amounts added } \\
(\mathrm{g} / \mathrm{kg})\end{array}$ & $27+I I$ & 44 & $29+I I$ & - & & 一 & 一 \\
\hline Food intake $(\mathrm{g} / \mathrm{d})$ & $8 \cdot 6$ & $5 \cdot 8$ & $8 \cdot 0$ & 0.37 & & $<0.001$ & Ns \\
\hline Weight gain $(\mathrm{g} / \mathrm{d})$ & 4.76 & $r \cdot 76$ & $3 \cdot 53$ & 0.24 & & $<0.001$ & $<0.01$ \\
\hline $\mathrm{M}$ activity $(\mu \mathrm{g} / \mathrm{ml})$ & 7 & 236 & 147 & $14.5 \ddagger$ & & $<0.001$ & $<0.01$ \\
\hline $\begin{array}{l}\text { Expt } 3 \\
\quad \text { Group no. } \ldots\end{array}$ & $\cdots$ & 2 & 3 & 4 & SE & $\begin{array}{l}\text { Linear } \\
\text { component }\end{array}$ & $\begin{array}{l}\text { Quadratici } \\
\text { component }\end{array}$ \\
\hline $\begin{array}{l}\text { Additions to a-a } \\
\mathrm{mix}\end{array}$ & $\mathrm{M}+\mathrm{C}$ & $\mathbf{M}+\mathbf{S}+\mathbf{C}$ & $\mathbf{M}+\mathrm{S}+\mathrm{C}$ & $\mathrm{S}+\mathrm{C}^{*}$ & - & - & - \\
\hline $\begin{array}{l}\text { Amounts added } \\
(\mathrm{g} / \mathrm{kg})\end{array}$ & $30+10$ & $20+I I+10$ & $10+22+10$ & $33+10$ & - & - & - \\
\hline Food intake $(\mathrm{g} / \mathrm{d})$ & $12 \cdot I$ & II.7 & $I I \cdot 9$ & Ir.4 & 0.26 & NS & NS \\
\hline $\begin{array}{l}\text { Weight gain }(\mathrm{g} / \mathrm{d}) \\
\mathrm{M} \text { activity }(\mu \mathrm{g} / \mathrm{ml})\end{array}$ & $\begin{array}{l}5 \cdot 15 \\
7\end{array}$ & $\begin{array}{l}5 \cdot 09 \\
56\end{array}$ & $\begin{array}{l}4 \cdot 74 \\
142\end{array}$ & $204^{3 \cdot 44}$ & $\begin{array}{l}0.33 \\
9.6\end{array}$ & $\begin{array}{l}<0.01 \\
<0.001\end{array}$ & $\begin{array}{l}\text { NS } \\
\text { NS }\end{array}$ \\
\hline
\end{tabular}

* Total $\mathrm{S}$ amino acids as methionine equivalents were $60 \mathrm{~g} / \mathrm{kg}$ a-a mix in Expts I and $2 a, 40 \mathrm{~g} / \mathrm{kg}$ in Expt $2 b$ and $42 \mathrm{~g} / \mathrm{kg}$ in Expt 3 .

$\dagger \mathbf{M}$ activities were determined in pooled samples.

$\mp$ Based on five determinations per group.

NS, not significant $(P>0.05)$. SE, pooled standard error. 
standard substance and in each run a pooled control sample of blood plasma from an earlier experiment was included. The mean of six assays on this sample was $93^{.6} \mu \mathrm{g} /$ $\mathrm{ml} \pm 7 \%$ (coefficient of variation). Methionine sulphoxide was found to be fully active for the test organism.

In Expt 4, whole blood was mixed with water $(1: 2, v / v)$ for haemolysis, before deproteinization with sodium tungstate.

The results were evaluated by analyses of variance, treatment sum of squares was subdivided into comparisons with one degree of freedom as described by Snedecor (1956).

\section{Design of experiments}

In all experiments except Expt 2 and Expt 6 four groups of rats were compared. In Expts 2 and 6 there were six groups. The amino acids used were all of the L-form. The total contents of $\mathrm{S}$ amino acids in the diets are expressed as methionine equivalents, calculated on the basis of their $\mathrm{S}$ content.

Expt I. Methionine, methionine plus cystine, methionine sulphoxide and methionine sulphoxide plus cystine were compared at the level of $60 \mathrm{~g} / \mathrm{kg}$ amino acid mixture or $9 \mathrm{~g} / \mathrm{kg}$ diet. Cystine replaced one-third of the methionine or methionine sulphoxide. The experiment lasted for $17 \mathrm{~d}$ and there were six rats/group.

Expt 2. Methionine plus cystine, methionine sulphoxide and methionine sulphoxide plus cystine were compared at 60 and $4 \circ \mathrm{g} / \mathrm{kg}$ amino acid mixture or 9 and $6 \mathrm{~g} / \mathrm{kg}$ diet, respectively. Cystine replaced one-third of the methionine or the methionine sulphoxide. The experiment lasted for $10 \mathrm{~d}$ and there were six rats/group.

Expt 3. In this experiment 0, 33, 67 and $100 \%$ of the methionine given was derived from methionine sulphoxide. The $\mathrm{S}$ amino acid level was $42 \mathrm{~g}$ methionine equivalents $/ \mathrm{kg}$ amino acid mixture or about $6 \mathrm{~g} / \mathrm{kg}$ diet. Cystine accounted for about $30 \%$ of this in all groups. The experiment lasted for ro $d$ and there were six rats/group.

Expts $4 a$ and $4 b$. In these experiments all groups were given the soya-bean-meal diet with added methionine or mixtures of methionine and methionine sulphoxide. The amounts were so chosen that the added amount plus the amounts of methionine and cystine originally present in the soya-bean meal corresponded to about $64 \mathrm{~g}$ methionine equivalents $/ \mathrm{kg}$ protein. The amounts of added methionine sulphoxide accounted for $12.5,25$, and $50 \%$ of the total methionine. Two parallel experiments were run. They were started at the same time and lasted for Io d (Expt $4 a$ ) or for $20 \mathrm{~d}(\operatorname{Expt} 4 b)$ and there were five rats/group.

Expt 5. In this experiment the unoxidized fish meal (no. I) and the oxidized fish meal (no. 2) were used as protein sources. One group was given the unoxidized meal and one group was given the oxidized meal. The two other groups were given mixtures of these meals so that one-third and two-thirds of the protein were either from the unoxidized or from the oxidized meal. Thus the comparisons were between diets containing $0,33,67$ and $100 \%$ of the protein from the oxidized fish meal. The experiment lasted for I I $d$ and there were six rats/group.

Expt 6. Methionine or methionine sulphoxide was added to fish meal no. $3(6 a)$ and to casein $(6 b)$ in amounts corresponding to $10 \mathrm{~g}$ methionine $/ \mathrm{kg}$ protein. Equivalent amounts of glycine were added to each protein source as a negative control. 
The experiment lasted for $9 \mathrm{~d}$, faeces and urine were collected for the last $5 \mathrm{~d}$ and there were four rats/group.

\section{RESULTS}

The results of Expts $1-3$ are given in Table 3 , those from Expts 4 and 5 are given in Table 4 and those from Expt 6 in Table 5. The amounts of amino acids added to the diets are indicated in the tables. Total amounts of $\mathrm{S}$ amino acids are given as methionine equivalents. The tables give mean food intakes and mean weight gains during the experimental periods and the mean amounts of methionine activity in the blood or in the blood plasma are tabulated together with the pooled standard errors.

\section{Growth of rats}

In Expt I (Table 3) where the $\mathrm{S}$ amino acid level was $60 \mathrm{~g} / \mathrm{kg}$ amino acid mixture, there were obviously poorer growth and less food intake when methionine sulphoxide accounted for the total amount of S amino acid (group 3). There were also obvious positive effects on both growth and food intake when part of the methionine sulphoxide was replaced by cystine (group 4). During the first Io $\mathrm{d}$ the rats in groups $\mathrm{I}, 2$ and 4 ate all the food offered.

Over-all, rats given methionine alone or with cystine (groups I and 2) grew better and ate more food than the corresponding rats given methionine sulphoxide (groups 3 and 4) $(P<0.001)$, and rats given cystine (groups 2 and 4$)$ grew better and ate more food than rats given no cystine (groups $\mathrm{I}$ and 3$)(P<0.001)$. The weight gains after Io and $\mathrm{I} 7 \mathrm{~d}$ on the diets showed the same general picture. Thus it was decided to rely mainly on $10 \mathrm{~d}$ periods in the other experiments.

In Expt 2 (Table 3) the S amino acid levels tested were 60 and $40 \mathrm{~g} / \mathrm{kg}$ amino acid mixtures. The analysis of variance showed that there was significant interaction $(P<0.05)$ between $\mathrm{S}$ amino acid levels and $\mathrm{S}$ amino acid supplements. Therefore each level was treated separately. At both levels group 2, given methionine sulphoxide, showed significantly poorer growth and less food intake than the groups given either methionine plus cystine or methionine sulphoxide plus cystine $(P<0.001)$. Between these two latter groups there was significant difference at the $40 \mathrm{~g} / \mathrm{kg}$ level $(P<0.0 \mathrm{I})$ but not at the $60 \mathrm{~g} / \mathrm{kg}$ level. Cystine was not so effective in improving growth at $4 \circ \mathrm{g} \mathrm{S}$ amino acid $/ \mathrm{kg}$ amino acid mixture as at $60 \mathrm{~g} / \mathrm{kg}$. The results obtained at the 60 and $40 \mathrm{~g} / \mathrm{kg}$ amino acid mixture when $44 \mathrm{~g}$ methionine sulphoxide $/ \mathrm{kg}$ amino acid mixture were given with and without cystine (Group 3 Expt $2 a$ and Group 2 Expt $2 b$, Table 3) showed that the improvement in growth in Expt I on substituting one-third of the methionine sulphoxide by cystine was not due to the reduced level of methionine sulphoxide alone. In Expt 3 the S amino acid level was $42 \mathrm{~g} / \mathrm{kg}$ amino acid mixture, and about $33 \%$ of this was cystine. The methionine sulphoxide content of the amino acid mixture was varied, so that it accounted for $0,33,67$ and $100 \%$ of the sum of methionine and methionine sulphoxide. Only when methionine sulphoxide accounted for all of the non-cystine $\mathrm{S}$ amino acids was a significantly lower growth rate observed $(P,<0.01)$. The linear component of the relationship between the methionine sulphoxide level and growth was significant $(P<0.01)$. In Expt 4 the amount of $\mathrm{S}$ 
Table 4. Mean food intakes $(\mathrm{g} / \mathrm{d})$, body-weight gains $(\mathrm{g} / \mathrm{d})$ and methionine $(M)$ activities in blood (Expts $4 a$ and $4 b)$ and in blood plasma $($ Expt 5$)(\mu \mathrm{g} / \mathrm{ml})$ of rats given soya-bean meal supplemented with methionine or mixtures of methionine and methionine sulphoxide $(S)$ (Expts $4 a$ and $4 b)$ and unoxidized $\left(F M_{\mathrm{I}}\right)$ and oxidized $\left(F M_{2}\right)$ fish meal alone or in combinations (Expt 5)

(Groups of five (Expts $4 a$ and $4 b$ ) and six male rats (Expt 5))

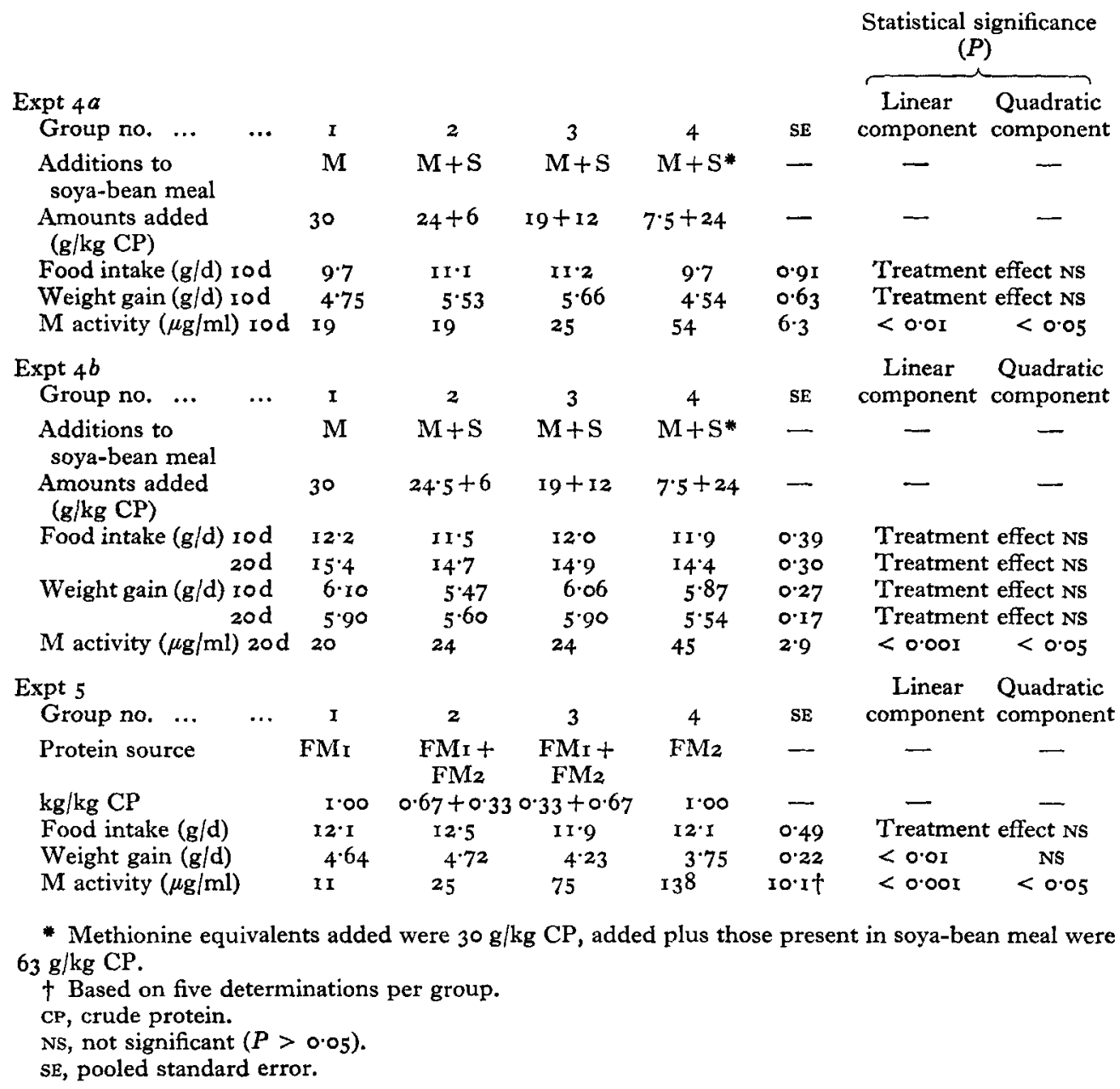

amino acids in the soya-bean-meal diet was doubled by adding either methionine alone or mixtures of methionine and methionine sulphoxide. The growth responses observed were not significantly different between groups even when methionine sulphoxide accounted for about $50 \%$ of the total methionine equivalents present as methionine and methionine sulphoxide or about $33 \%$ of the total $\mathrm{S}$ amino acid equivalents. This was so both in the $10 \mathrm{~d}$ and $20 \mathrm{~d}$ part of the experiment. In Expt 5 mixtures of unoxidized and oxidized fish meal showed significantly reduced growth 


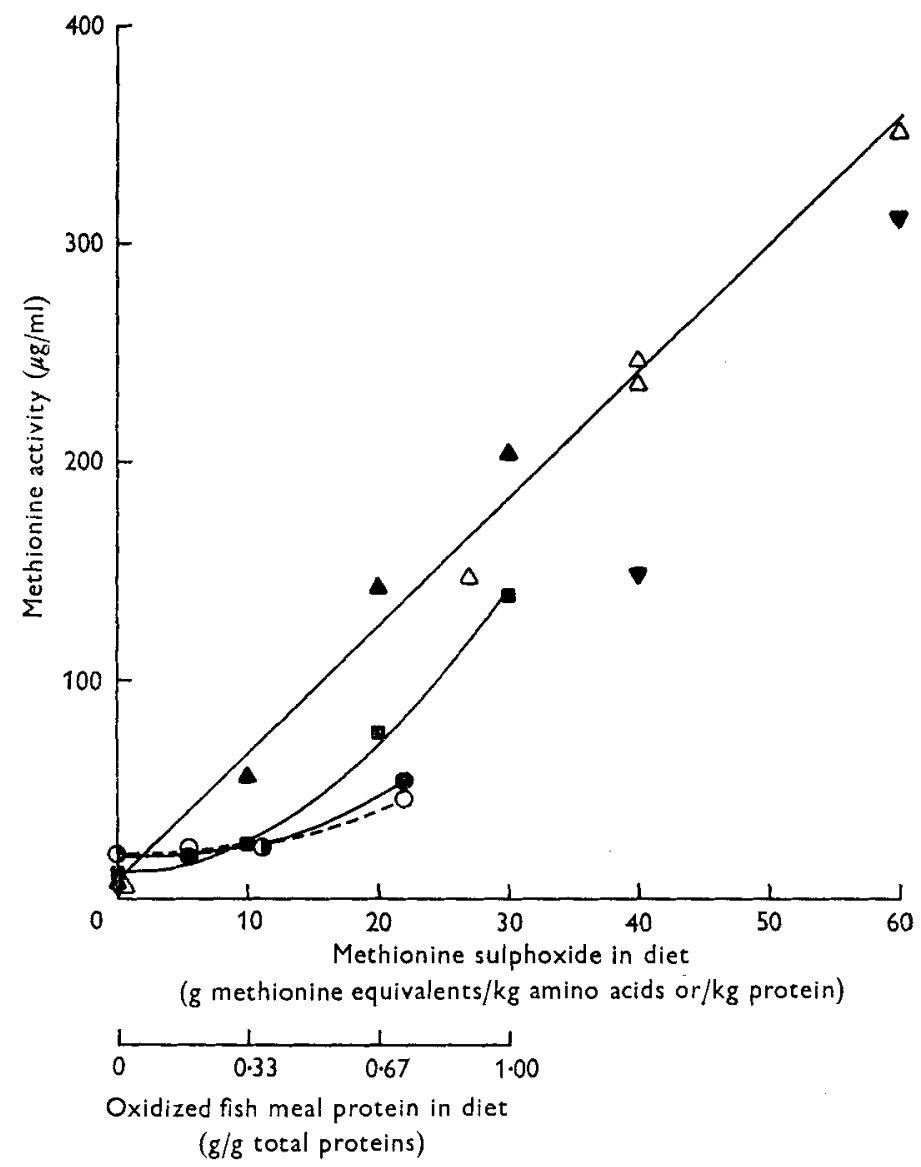

Fig. 1. Methionine activity in blood plasma (Expts $1-3,5$ ) or in haemolysed blood (Expt 4) of rats $(Y)$ v. methionine sulphoxide added to the diet $(\mathrm{g}$ methionine equivalents $/ \mathrm{kg}$ amino acid mixture, or $\mathrm{g} / \mathrm{kg}$ protein) or $v$. proportion of oxidized fish meal protein (no. 2) mixed with unoxidized fish meal protein (no. I) in the diet $(X)$. Each point is the mean for five or six rats in all experiments except Expt $I_{2}$ in which pooled samples were analysed. $\nabla$ Expt I

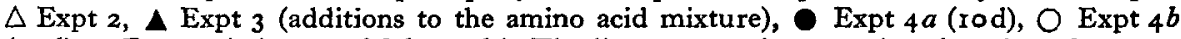
(2od), Expt 5 (mixture of fish meals). The linear regression equations based on the mean values were: Expt 2: $Y=5.78 X+4.44(r+0.998)$, Expt 3: $Y=6.74 X+0.90(r=+0.995)$, Expts $(2+3): Y=5.83 X+7.93(r=+0.995)$.

only when the oxidized fish meal was given alone $(P<0.01)$. In this experiment the rats grew rather slowly during the first $3 \mathrm{~d}$, but at a good rate later on.

\section{Methionine activity in blood}

In Expts I-3 (Table 3), methionine sulphoxide in the diet resulted in high values for methionine activity in the plasma as determined microbiologically. The rats given equal levels of methionine sulphoxide with and without added cystine in a rod period (group 3, Expt $2 a$ and group 2, Expt $2 b$ ) showed a non-significant difference in mean plasma activities, $(246 v .236 \mu \mathrm{g} / \mathrm{ml})$. The food intakes were different so that the amount of methionine sulphoxide eaten was higher in the former case. 
Table 5. Expt 6. Nitrogen balances expressed as proportion of intake in rats given casein or fish meal no. $3^{*}$ fortified with methionine $(M)$ or methionine sulphoxide $(S)$ (glycine $(G)$ was used as negative control)

(Groups of four male rats)

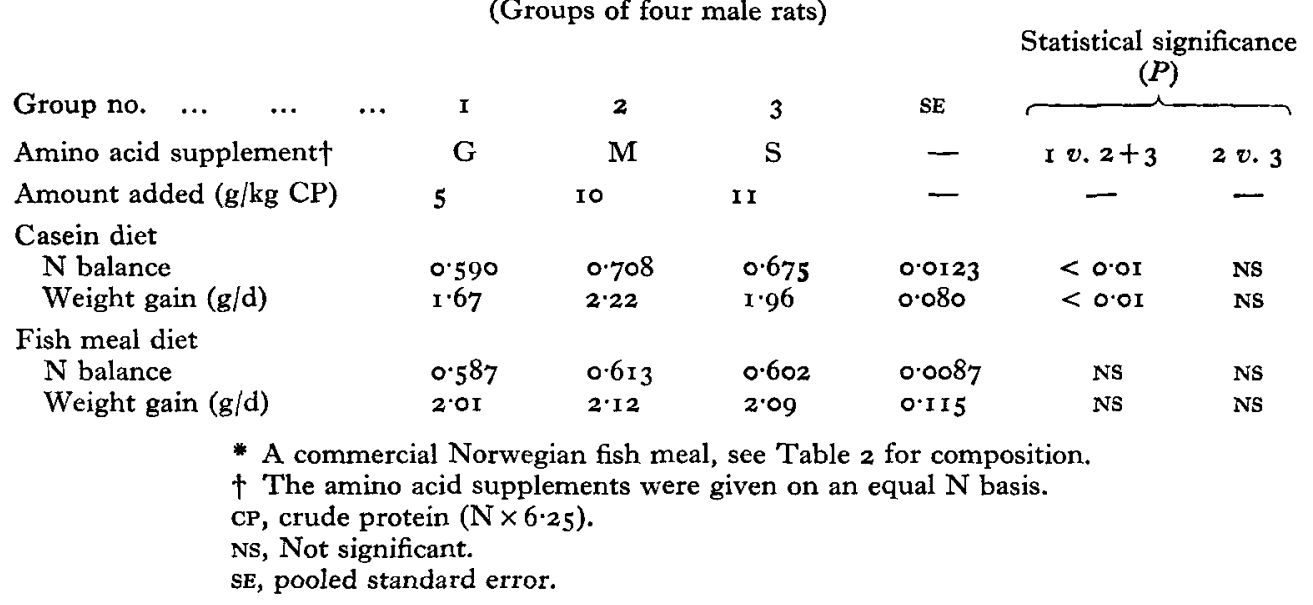

The results obtained in Expts 2 and 3 showed a linear relationship between $g$ methionine sulphoxide $/ \mathrm{kg}$ amino acid mixture and the level of methionine activity in the blood plasma (Fig. I). The observations in Expt $I$ are also shown. The latter, which were obtained after $17 \mathrm{~d}$ on the experimental diets, were comparatively lower than the former, which were obtained after ro d.

In Expts 4 and 5 the level of methionine activity in the blood or in plasma increased with increasing amounts of methionine sulphoxide in the diet. The observed values were, however, lower than those observed with corresponding methionine sulphoxide levels in the amino acid mixtures (Fig. I). In all experiments the analyses of variance showed that there were significant differences between groups.

In Expt 4 and Expt 5 there were statistically significant linear $(P<0.01)$ and quadratic $(P<0.05)$ components in the treatment sum of squares. Therefore, in these experiments the lines are drawn curvilinearly in Fig. I.

\section{Balance experiment}

The analysis of variance of the N-balance experiment (Expt 6) showed that casein was significantly better utilized than fish meal $(P<0.05)$. There were also significant differences due to the different amino acid supplements $(P<0.001)$, but because there was significant interaction between the protein sources and the amino acid supplements $(P<0.01)$ the data for the protein sources were treated separately. For casein, methionine and methionine sulphoxide both improved the $\mathrm{N}$-balance as compared with the negative control $(P<0.001)$, whereas the difference between the two former was insignificant. For the fish meal there was no significant difference between amino acid supplements. 


\section{Methionine sulphoxide in blood plasma}

By the method used, methionine sulphoxide and aspartic acid appeared as one peak on the chromatograms. In Expt 5, plasma from rats given oxidized fish meal alone showed a peak in this position which by calculation corresponded to $130 \mu \mathrm{g}$ methionine sulphoxide/ml. In plasma from rats given unoxidized fish meal the corresponding peak accounted for about ro $\mu \mathrm{g}$ methionine sulphoxide/ml. Probably only a minor part of this is due to aspartic acid, as values reported in the literature range from I to $3 \mu \mathrm{g} / \mathrm{ml}$ plasma (Harker, Allen \& Clark, I968; Lakhanpal, Harrill \& Bowman, I969). The difference between the plasma values, $120 \mu \mathrm{g}$ methionine sulphoxide $/ \mathrm{ml}$, is in fair agreement with the results obtained microbiologically. Thus, feeding on the oxidized fish meal gave rise to increased amounts of a substance in the blood plasma which occupied the same position as methionine sulphoxide in the chromatograms.

\section{DISCUSSION}

\section{Growth and $N$ balance}

The biological availability of methionine sulphoxide is of importance as methionine is rather easily oxidized to the sulphoxide. Oxidation to methionine sulphone requires more drastic treatment. Recent papers by Dévényi, Báti, Hallstrøm, Trägårdh, Kralovánszky \& Mátrai (1974) and by Pieniąźek, Rakowska \& Kunachowicz (1975) and Pieniąźek, Rakowska, Szkilłądziowa \& Grabarek (1975) describe methods of determining chemically the unoxidized methionine. The amount of methionine so determined was termed 'available' and it was thus implied that methionine sulphoxide is not a fully available form of methionine. No evidence was given, however, about methionine sulphoxide utilization by experimental animals. The implication is in accord with the results reported by Miller \& Samuel (r968, r970), Ellinger \& Palmer (1969) and Miller et al. (1970), but not with those reported by Bennett (1939), Tsuchiya (1942a,b), Njaa (1962b) and Slump \& Schreuder (1973).

Our work goes some way towards explaining the conflicting results obtained by the various authors. It was found that methionine sulphoxide was poorly utilized when cystine was not present in the amino acid mixture, and that the utilization was greatly improved when cystine replaced part of the sulphoxide. The findings of Miller \& Samuel (1968, 1970) and of Ellinger \& Palmer (1969), that methionine sulphoxide was poorly utilized either when added to a casein diet or when it was present in proteinbound form in oxidized casein, may probably be explained by the low content of cystine in casein. This explanation is not, however, valid to explain the results obtained by Slump \& Schreuder (1973) with oxidized casein which contained very little cystine. Their analytical data show that the oxidation led to greater destruction of methionine and cystine in casein than in fish meal. As a result the nutritive value of the casein was more affected than that of the fish meal.

Our fish meals were unusually low in cystine, and the values reported were confirmed by analyses of samples oxidized to cysteic acid with performic acid. We have therefore decided to study the utilization of free and protein-bound methionine 
sulphoxide in fish meals more thoroughly. These experiments, which require knowledge of the content of methionine sulphoxide in the fish meals, have been started.

The other experiments with methionine sulphoxide added to diets were all done with protein sources known to contain greater amounts of cystine. Thus, Bennett (1939) used arachin, Tsuchiya (1942a,b) used dried milk and Njaa (1962b) used soya-bean meal, all of which contain higher amounts of cystine than does casein. It was mentioned previously that the amino acid mixture used by Miller $e t$ al. (1970) did not contain cystine. Thus, the results indicate that when methionine sulphoxide is the sole source of $\mathrm{S}$ amino acids synthesis of cystine is too slow to allow good growth. On the other hand, when cystine is present the reduction to methionine is fast enough to allow nearly the same growth rate as when methionine is given alone or with cystine. In the N-balance experiment (Expt 6) with fish meal or casein as the protein source, methionine and methionine sulphoxide both improved the $\mathrm{N}$-balance for the casein. For fish meal there was no significant effect of the supplements. For casein the effect of methionine sulphoxide was less than that of methionine, but the difference was not significant. The fact that the utilization of casein was improved by the methionine sources, whereas that of fish meal was not, may indicate that in this particular fish meal there may have been another amino acid besides methionine which was limiting protein utilization. Usually methionine supplementation is found to improve the utilization of fish-meal protein (Miller, 1956; Njaa, I96r).

The results with the oxidized fish meal indicated that amino acids other than the $\mathrm{S}$ amino acids were not affected by the oxidation procedure to any great extent. Amino acid analyses of the two fish meals confirmed this, as only a slightly lower value was found for tryptophan in the oxidized meal than in the unoxidized meal. The high lysine value in the oxidized meal may be a result of a concentration effect of the procedures used. The water-soluble part was discarded during the preparation and washing procedures. Our results with these fish meals are in general agreement with those of Slump \& Schreuder (1973).

\section{Methionine activity in blood}

In our first experiment we confirmed the finding of Miller et al. (1970) that giving a diet containing methionine sulphoxide results in high levels of methionine activity in blood plasma. The two later experiments (Expts 2 and 3) showed that there was a linear relationship between the content of methionine sulphoxide in the diet and the methionine activity in the blood. The two groups in Expt 2 which had the same amount of methionine sulphoxide in the diet with and without added cystine (group 3, Expt $2 a$ and group 2, Expt $2 b$, Table 3) showed approximately the same methionine activity in the blood plasma. Therefore it seems that the high plasma activity in itself did not depress growth. The observation that the methionine activity in Expt I was apparently lower than in Expts 2 and 3 may probably be explained by the fact that the former lasted for $17 \mathrm{~d}$ whereas the two latter lasted for $10 \mathrm{~d}$. Miller et al. (1970) reported that the methionine activity was lower in older rats than in younger rats. In the rats given either methionine sulphoxide added to a soya-bean-meal diet or methionine sulphoxide in the form of oxidized fish meal, appreciably lower values 
were found for methionine activity than would have been expected from the content of sulphoxide (Fig. I). In Expt 4, the results refer to whole blood but control experiments showed that plasma values for the same rats were even lower than those found in whole blood. We had hoped that the plasma methionine activity might have been a useful indication of the presence of methionine sulphoxide in protein sources fed to rats. The experiments with a synthetic amino acid mixture were hopeful in this respect. However, the results obtained both with methionine sulphoxide added to a soya-bean-meal diet and with the mixtures of unoxidized and oxidized fish meals showed that this indicator was of limited value. Thus plasma methionine activity was not significantly augmented before methionine sulphoxide accounted for more than $30 \%$ of the total $\mathrm{S}$ amino acids.

The identity of the substance in the blood plasma accounting for the methionine activity was not established, but the chromatographic data indicated that it might be methionine sulphoxide. The sulphoxide also showed practically full methionine activity in the microbiological assay. These findings are not in agreement with the results reported by Miller et al. (1970).

\section{REFERENCES}

Bennett, M. A. (1939). Biochem. $\mathcal{F . ~ 3 3 , ~} 1794$.

Cuq, J. L., Provansal, M., Guilleux, F. \& Cheftel, C. (1973). F. Fd Sci. 38, ir.

Dévényi, T., Báti, J., Hallstrøm, B., Trägårdh, Ch., Kralovánszky, P. U. \& Mátrai, T. (1974). Acta biochim. biophys. Acad. Sci. Hung. 9, 395.

Ellinger, G. M. \& Palmer, R. (1969). Proc. Nutr. Soc. 28, 42 A.

Floyd, N. F., Cammaroti, M. S. \& Lavine, T. F. (1963). Archs Biochem. Biophys. 102, 343.

Greenfield, H., Briggs, G. M., Watson, R. H. J. \& Yudkin, J. (1969). Proc. Nutr. Soc. 28, 43 A.

Harker, C. S., Allen, P. E. \& Clark, H. E. (1968). F. Nutr. 94, 495.

Lakhanpal, R. K., Harrill, I. \& Bowman, F. (I969). F. Nutr. 99, 497.

Lea, C. H., Parr, L. J. \& Carpenter, K. J. (1958). Br. F. Nutr. 12, 297.

Lunder, T. L. (1972). Analyt. Biochem. 49, 585.

McLaughlan, J. M., Noel, F., Morrison, A. B. \& Campbell, J. A. (r96r). Can. F. Biochem. Physiol. 39, 1669 .

Miller, D. S. (1956). F. Sci. Fd Agric. 7, 337.

Miller, D. S. \& Samuel, P. (1968). Proc. Nutr. Soc. 27, 2 I A.

Miller, D. S. \& Samuel, P. D. (r970). F. Sci. Fd Agric. 21, 6 r6.

Miller, S. A., Tannenbaum, S. R. \& Seitz, A. W. (1970). F. Nutr. 100, 909.

Njaa, L. R. (I959). Br. F. Nutr. I3, I37.

Njaa, L. R. (1961). F. Sci. Fd Agric. 12, 757.

Njaa, L. R. ( (96za). Acta chem. scand. 16, 1359.

Njaa, L. R. $(196 z b)$. Br. F. Nutr. x6, 571 .

Njaa, L. R. (1963). Fisk.Dir. Skr. 4, no. 5.

Pieniąźek, D., Rakowska, M. \& Kunachowicz, H. (1975). Br. F. Nutr. 34, I63.

Pieniąźek, D., Rakowska, M., Szkiłłądziowa, W. \& Grabarek, Z. (1975). Br. F. Nutr. 34, 175.

Rasekh, J., Stillings, B. R. \& Sidwell, V. (1972). F. Fd Sci. 37, 423.

Slump, P. \& Schreuder, H. A. W. (1969). Analyt. Biochem. 27, 182.

Slump, P. \& Schreuder, H. A. W. (1973). F. Sci. Fd Agric. 24, 657.

Snedecor, G. W. (1956). Statistical Methods Applied to Experiments in Agriculture and Biology, 5 th ed., Chapter 12. Ames, Iowa: Iowa State College Press.

Tannenbaum, S. R., Barth, H. \& LeRoux, J. P. (1969). F. agric. Fd Chem. 17, 1353.

Tsuchiya, Y. (1942a). Bull. agric. chem. Soc. fap. 18, 23.

Tsuchiya, Y. (1942b). F. agric. chem. Soc. Fap. 18, 279. 